\title{
Diatoms Si uptake capacity drives carbon export in coastal upwelling systems
}

\author{
Fatima Abrantes $^{1,2}$, Pedro Cermeno ${ }^{3}$, Cristina Lopes ${ }^{1,2}$, Oscar Romero ${ }^{4}$, Lélia Matos ${ }^{1,4}$, Jolanda Van Iperen ${ }^{5}$, \\ Marta Rufino ${ }^{1,2}$, and Vitor Magalhães ${ }^{1}$ \\ ${ }^{1}$ Portuguese Institute for the Ocean and Atmosphere, Rua Alferedo Magalhães Ramalho 6, 1495-006 Lisbon, Portugal \\ ${ }^{2}$ Centre of Marine Sciences (CCMAR-LA), Universidade do Algarve, Campus de Gambelas, 8005-139 Faro, Portugal \\ ${ }^{3}$ Institute of Marine Sciences (ICM-CSIC), Passeio Marítim de la Barceloneta, 37-49, 08003 Barcelona, Spain \\ ${ }^{4}$ Center for Marine Environmental Sciences University of Bremen (MARUM), Leobener Str., 28359 Bremen, Germany \\ ${ }^{5}$ Royal Netherlands Institute for Sea Research (NIOZ), Landsdiep 41797 SZ 't Horntje (Texel), the Netherlands \\ Correspondence to: Fatima Abrantes (fatima.abrantes@ipma.pt)
}

Received: 11 October 2015 - Published in Biogeosciences Discuss.: 22 February 2016

Revised: 13 June 2016 - Accepted: 21 June 2016 - Published: 18 July 2016

\begin{abstract}
Coastal upwelling systems account for approximately half of global ocean primary production and contribute disproportionately to biologically driven carbon sequestration. Diatoms, silica-precipitating microalgae, constitute the dominant phytoplankton in these productive regions, and their abundance and assemblage composition in the sedimentary record is considered one of the best proxies for primary production. The study of the sedimentary diatom abundance (SDA) and total organic carbon content (TOC) in the five most important coastal upwelling systems of the modern ocean (Iberia-Canary, Benguela, Peru-Humboldt, California, and Somalia-Oman) reveals a global-scale positive relationship between diatom production and organic carbon burial. The analysis of SDA in conjunction with environmental variables of coastal upwelling systems such as upwelling strength, satellite-derived net primary production, and surface water nutrient concentrations shows different relations between SDA and primary production on the regional scale. On the global scale, SDA appears modulated by the capacity of diatoms to take up silicic acid, which ultimately sets an upper limit to global export production in these ocean regions.
\end{abstract}

\section{Introduction}

Coastal upwelling zones exist along the eastern boundary currents of the Atlantic and Pacific oceans. In these areas, alongshore equatorward winds and the Coriolis effect force surface waters to diverge offshore, giving rise to the upwelling of nutrient-rich deep waters into the surface. The five most important coastal upwelling systems of the modern ocean are associated with (1) the Canary Current off northwestern Africa, including its extension to the Iberian Peninsula (Iberia-Canary), (2) the Benguela Current along southwestern Africa, (3) the Peru-Humboldt Current off western South America (southeastern Pacific), (4) the California Current off western North America (northeastern Pacific), and (5) the Somalia-Oman monsoon-derived upwelling off the Arabian Peninsula (Barber and Smith, 1984; Hill et al., 1998). At present, oceanic primary production represents $50 \%$ of Earth's primary production, and its highest contribution originates from the $\pm 1 \%$ of the ocean characterized by coastal upwelling (Field et al., 1998; Hill et al., 1998).

The potential role of coastal upwelling systems in carbon uptake and export turns their dominant phytoplankton, the diatoms, into key players of marine planktonic food webs and the carbon cycle (Field et al., 1998). Diatoms require dissolved silica (as orthosilicic acid, $\mathrm{H}_{4} \mathrm{SiO}_{4}$ ), which they precipitate from seawater, to form their opal (amorphous hydrated Si) frustules (Lewin and Guillard, 1963), making 
coastal upwelling areas also a major Si sink (Tréguer and De La Rocha, 2013).

The prolific diatom-dominated blooms that respond to episodic inputs of nutrients are dominated by chain-forming marine species of the genus Chaetoceros Ehrenberg (Estrada and Blasco, 1985). Maximum fluxes of this genus coincide with intervals of increased nutrient availability in most coastal upwelling regions: California (Sancetta, 1995); Humboldt (Romero et al., 2001); Iberia-Canary (Wefer and Fisher, 1993; Lange et al., 1994; Treppke et al., 1996b; Abrantes et al., 2002); Benguela (Treppke et al., 1996a; Romero et al., 2002); and Somalia-Oman (Nair et al., 1989; Koning et al., 2001), attesting to their great capacity for C export.

Although only a minor percentage (1-4\%) of the initial diatom population gets preserved in the sediments (e.g., Takahashi et al., 1989; Sancetta, 1992; Abrantes et al., 2002), the fact that Chaetoceros species produce heavily silicified spores with high sinking rates leads to a sedimentary assemblage dominated by the water-column blooming species; furthermore, the positive relationship between abundance of diatom frustules and content of organic carbon in sediments beneath major upwelling systems (Iberia-Canary system, Abrantes, 1988; Nave et al., 2001; Benguela system, Schuette and Schrader, 1981; Peru-Humboldt system, Abrantes, 2007; northern California system, Lopes et al., 2006) suggests that estimates of sedimentary diatom abundance (no. of valves/g - SDA) is representative of $\mathrm{C}$ export production in coastal upwelling regions. In support of this relationship, time series of organic carbon content and diatom abundance from Atlantic coastal upwelling sites indicate concomitant variations of the two productivity proxies (e.g., Muller and Suess, 1979; Abrantes, 2000). Conversely, other sequences from the northwestern and southwestern African margins show contradictory results (e.g., Caulet et al., 1992; Heinze and Wefer, 1992; Martinez et al., 1999). A time series located off the Oregon coast (Lopes et al., 2014) also shows disagreement between carbon- and diatom-based estimates of primary productivity. In this record high abundances of small diatoms, which dominate highly productive ecosystems, co-occur with low concentrations of total organic carbon (TOC) in the sediments, while higher carbon burial rates seem to be associated with the accumulation of large diatoms typical of unproductive environments.

It has long been recognized that both the physical and chemical processes as well as the biological response in coastal upwelling have a non-linear and complex relationship (Barber and Smith, 1981). Furthermore, intra- and interregional variability is known to be extensive through space and time, demanding dynamical and fine-scale biological modeling to faithfully understand those complex interactions. Here we analyze an extensive data set of sedimentary diatom abundance (SDA for 703 sites) and organic carbon content (TOC for 200 sites) in concert with mean annual values of net primary production, upwelling index, and seawater nutrient concentrations extracted from long time series and global climatologies to assess the main factors controlling SDA. Our study relies on two main arguments: (1) it is possible to make generalizations about the functioning of coastal upwelling ecosystems (Barber and Smith, 1981); and (2) the sediments retain the imprint of the different processes that, on average, determine the physical, chemical, and biological properties of coastal upwelling ecosystems.

\section{Materials and methods}

The used data set comprises 703 sediment samples recovered from the five most important coastal upwelling areas of the modern ocean, collected by different institutions and sampling processes (box-, multi- and in some cases pistoncoring devices since the 1970s). For the analysis, the topmost sediment $(0-1$ or $0-2 \mathrm{~cm})$ was used (Fig. 1; data available at doi:10.1594/PANGAEA.859881). Calibration between the diatom data produced by different researchers followed the process described by Abrantes et al. (2005) and counting principles defined by Schrader and Gersonde (1978). Obtained values are given as the number of valves $\mathrm{g}^{-1}$ of dry sediment (no. of valves $/ \mathrm{g}^{-1}$ ) and show 4 orders of magnitude in variability, between $10^{5}$ and $10^{9}$. Considering that cell growth is exponential, and to avoid the effect of extreme values and preserve minor variability within each order of magnitude, the data are plotted as its natural $\log (\ln )$.

Organic carbon content (TOC - wt \%) for Galicia, the Portuguese margin, northwestern Africa-Canaries, and the southeastern and northeastern Pacific was measured following the methodology in use at the IPMA sedimentology and micropaleontology laboratory. Three replicates of $2 \mathrm{mg}$ subsamples of each dried and homogenized sediment sample are measured, before and after combustion, on a CHNS-932 LECO elemental analyzer. The relative precision of repeated measurements of both samples and standards was $0.03 \mathrm{wt} \%$.

Upwelling indices were determined according to the National Oceanic and Atmospheric Administration (NOAA) procedure (Bakun, 1973) - http://www.pfeg.noaa.gov/ products/las/docs/global_upwell.html. Geostrophic winds were calculated from the FNMOC 6-hourly pressure analysis $\left(1^{\circ}\right.$ grid $)$ and further used to calculate wind stress and Ekman transport. Finally, the Ekman transport is rotated to get the offshore component (provided that the orientation of the coast is known), and a monthly upwelling index was obtained for each site location from 1969 to 2013.

Net primary production (NPP) data were provided by the Oregon State University Ocean Productivity Center (http: //www.science.oregonstate.edu/ocean.productivity/) as mean annual and seasonal values for the available 10-year data set (2003-2013). NPP is determined by the Vertically Generalized Production Model (VGPM) and is a function of chlorophyll, available light, and the photosynthetic efficiency (Behrenfeld and Falkowski, 1997). 


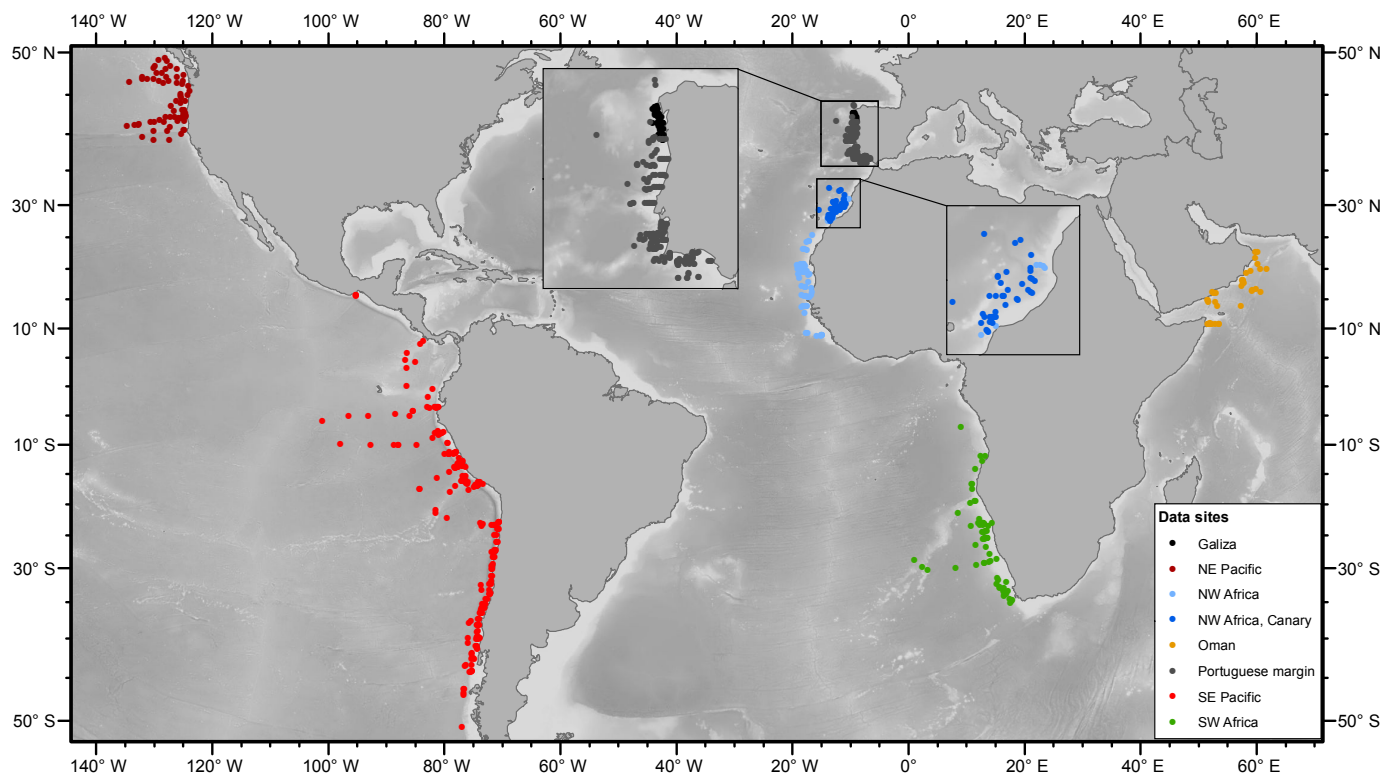

Figure 1. Geographic distribution of the total data set sites considered in this study. Map in WGS84 and Mercator projection. Different colors represented different upwelling systems.

The World Ocean Atlas 2013 (WOA13) is the source of in situ measured phosphate, silicate, and nitrate at $\mu$ Mat standard depth levels and for annual, seasonal, and monthly composite periods (Garcia et al., 2014). Surface values correspond to the $10 \mathrm{~m}$ water depth and bottom data comprise the closest available value for each sample site water depth.

To address the long-term global relationship between SDA and all the environmental variables, escaping the temporal variability (seasonal and annual) within and between regions, we used the annual mean value estimated from the number of years of available data. Regressions between SDA and each variable annual mean were calculated and the corresponding plot generated for the entire data set as well as for the sites confined to the main upwelling zone of each system. The latitudinal boundaries for each main upwelling area were set to include seasonal upwelling regions and followed Rykaczewski et al. (2015).

\section{Results and discussion}

\subsection{Sedimentary total organic carbon content (TOC) and diatom abundance (SDA)}

Our data set allows evaluation of the relationship between SDA and TOC per geographic region and globally (200 sites; Table 1 and Fig. 2). No relationship exists for the Canary upwelling system (Galicia to the Canaries) and the Benguela and Peru-Humboldt systems, but a positive and significant relationship was found for the California system (northwestern Pacific) $\left(R^{2}=0.98, p=0.01, n=5\right)$. When the entire existing data set is considered, a significant positive rela- tion is obtained $\left(R^{2}=0.40, p=0.01, n=200\right)$. These results suggest that small-scale regional conditions are likely to determine different SDA and TOC accumulation loci. Diatoms give a detailed picture of the centers of maximum annual primary production generated during the upwelling season (Nelson et al., 1995; Abrantes and Moita, 1999). TOC is indicative of the mean annual production (independent of the generating process), and a stronger SDA-TOC relationship occurs in centers of preferential accumulation of fine-grained sediments, such as off large river mouths (e.g., Reimers and Suess, 1983; Abrantes, 1988; Abrantes et al., 2004). On a global scale, the covariance between SDA and TOC is likely to reflect the higher annual contribution of diatoms to total carbon export in the high-Si coastal upwelling systems.

When dealing with sediment components, however, one has to verify to what extent sedimentary processes can alter the sediment record. Both diatom and organic carbon burial success depend on (1) the sealing effect provided by the rate of contribution of other particles to the bulk sediment, that is, sediment accumulation rate (MAR), and (2) early diagenetic processes on the seafloor (Broecker and Peng, 1982).

\subsubsection{Sealing effect}

MAR corresponds to the amount of sediment deposited by unit of area and time, is expressed in $\mathrm{g} \mathrm{cm}^{-2} \mathrm{ky}^{-1}$, can only be calculated if the age of the sediments is known, and is subject to errors that can be caused by faulty age models or processes like sediment focusing by bottom currents. Such problems can only be circumvented through the combined use of MAR estimation from excess ${ }^{230} \mathrm{Th}$ determinations (Lyle et al., 2014). For our sites, few or no ${ }^{230} \mathrm{Th}$ data are available, 


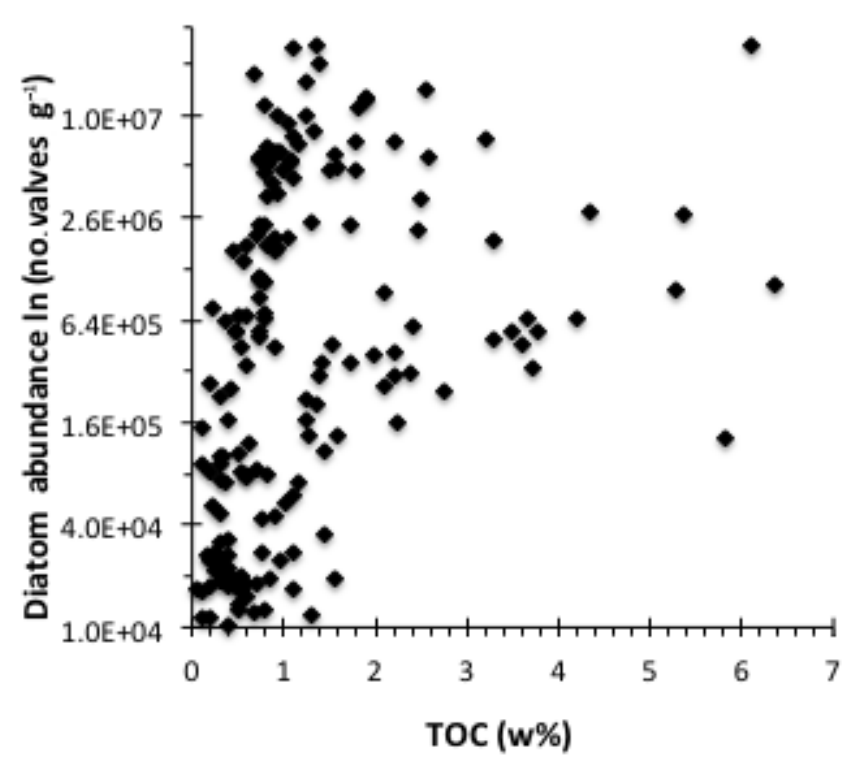

Figure 2. Relationship between total marine diatom abundance $\ln$ (no. of valves $\mathrm{g}^{-1}$ ) and total organic carbon content wt \%) for the Canary (Galicia to the Canaries), Humboldt (southeastern Pacific), and California (northeastern Pacific) systems.

and dated cores are scarce and punctual, reducing the original data set to 28 sites (Table S2 in the Supplement). We used these data to investigate the possible influence of MAR variability on diatom accumulation rate (DAR) according to

DAR (no. valves $\mathrm{cm}^{-} 2 \mathrm{ky}^{-1}$ ) $=$ Diatom abundance $\left(\mathrm{SDA}-\right.$ no.valves $\left.\mathrm{g}^{-1}\right) \times \operatorname{MAR}\left(\mathrm{g} \mathrm{cm}^{-} 2 \mathrm{ky}^{-1}\right)$,

where MAR $\left(\mathrm{g} \mathrm{cm}^{-2} \mathrm{ky}^{-1}\right)$ is calculated by multiplying the sedimentation rate $\left(\mathrm{SR}, \mathrm{cm} \mathrm{yr}^{-1}\right)$ by the sediment dry bulk density $\left(\mathrm{g} \mathrm{cm}^{-3}\right)$.

Sediment dry bulk density is also not available for the majority of the dated cores, but one can consider its variability between 0.7 and $2 \mathrm{~g} \mathrm{~cm}^{-3}$ (authors' laboratory data for thousands of samples). SR was determined on the basis of the two topmost published radiocarbon dates for each site (Table S2). Both DAR and MAR were estimated using the minimum, mean, and maximum dry bulk density $(0.7$, 1.4 , and $2 \mathrm{~g} \mathrm{~cm}^{-3}$; Fig. S1a, b in the Supplement). The results reveal that SDA is not dependent on MAR $\left(R^{2}=0.01\right)$, but DAR values are mainly controlled by diatom abundance $\left(R^{2}=0.90\right)$.

When the same exercise is performed for TOC concentrations, the data set gets reduced to 10 sites, which is not representative of all five areas and displays no relation to either $\operatorname{MAR}\left(R^{2}=0.18\right.$ at $p=0.1$ and $\left.n=10\right)$ or TOC accumulation rate $\left(R^{2}=0.62\right.$ at $p=0.1$ and $\left.n=10\right)$.

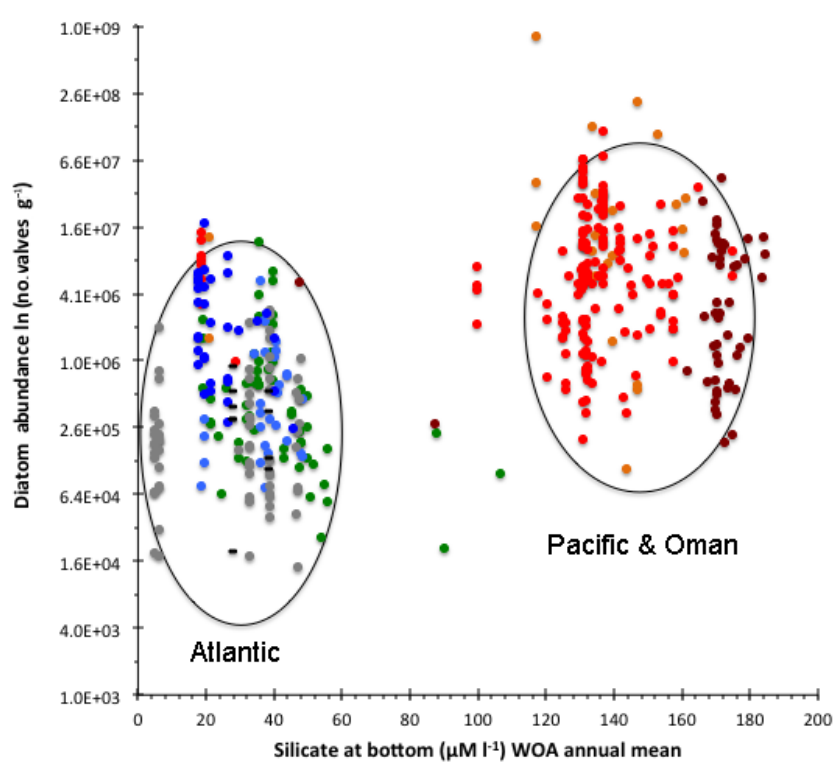

Figure 3. Relationship between total marine diatom abundance $\ln$ (no. of valves $\mathrm{g}^{-1}$ ) and bottom-water $\left[\mathrm{Si}(\mathrm{OH})_{4}^{-}\right]$in $\mu \mathrm{M}$ from the WOA 2009 database. Color scheme as in Fig. 1.

\subsubsection{Diatom and TOC diagenetic effects at the seafloor}

Diatom dissolution on the seafloor, although influenced by factors such as $\mathrm{pH}$, temperature, organic matter, and metal ions associated with the frustule surface, is mainly determined by the degree of Si saturation in the medium, that is, the concentration of silicic acid in the bottom waters (e.g., Lewin and Guillard, 1963; Hurd and Takahashi, 1982; Van Bennekom and Berger, 1984; Van Cappellen et al., 2002).

No relation between SDA and concentrations of silicic acid in deep waters was found at the regional level (Fig. S2). Throughout the world's oceans, the pathway of thermohaline deep water circulation generates inter-basin differences in the concentration of silicic acid, which increases as deep waters flow from the Atlantic Ocean to the Southern and Pacific basins (Rageneau et al., 2000). The comparison of bottom $\left[\mathrm{Si}(\mathrm{OH})_{4}\right]$ to SDA at our sites displays the two expected clusters that separate the lower silicate of the Atlantic vs. the higher silicate of the Pacific (Fig. 3). Furthermore, the mean SDA (ln transformed) values for the two clusters are statistically different $(t$ test: $T=-20.481, p<$ 0.001 , mean Atlantic $=5.606 \pm 0.072$ and mean Pacific Indian $=6.696 \pm 0.076$ ), but a large overlap within the diatom abundance of the two clusters is also evident. These results indicate that despite the diatom losses related to the seafloor $\left[\mathrm{Si}(\mathrm{OH})_{4}\right]$, the preserved sediment diatom signal carries generalized information that overrides the result of dissolution effects.

As for TOC, the preservation of the organic material that escapes water-column degradation and reaches the bottom is dependent on the type of organic matter, bioturbation 
level, and bottom-water oxygenation (Emerson, 1985; Canfield, 1994; Zonneveld et al., 2010). Aside from the longstanding debate regarding the kinetics of organic matter decomposition at different bottom-water $\mathrm{O}_{2}$ concentrations, Canfield (1994) showed that in regions with high rates of organic carbon deposition (typical of continental margins), differences in preservation are weakly dependent on bottomwater $\mathrm{O}_{2}$ concentrations.

\subsection{Upwelling intensity and SDA}

In the modern subtropical ocean, coastal upwelling is mostly seasonal (spring-summer), but it can also be perennial at lower latitudes such as off Cape Blanc (Canary system), Walvis Bay (Benguela system), and Peru (Humboldt system). Inter-annual atmospheric and oceanic variations can cause latitudinal extension and retraction in the seasonal spatial coverage of each system as well as in the offshore extension of upwelling filaments. The best-known and dramatic inter-annual variations in coastal upwelling-derived primary production occur in the Humboldt-Peru system, caused by the El Niño-Southern Oscillation (ENSO) cycle (Barber and Kogelschatz, 1990; Philander, 1990).

To investigate the possible effect of upwelling strength on sediment diatom abundance, we used the 47-year time series of the annually averaged upwelling index estimated for each sample site following the method of Bakun (1973), a method that can generate errors for sites located close to the Equator or within $1^{\circ}$ off the coast, that is, the inner-shore areas that are most influenced by the coastal upwelling process, and where a large number of our sites are located (519 in total Fig. S3). An alternative approach would be the use of local wind data sets, but problems arise from the fact that different areas have dissimilar data sets in terms of time length as in the index calculation approach. As such, we decided to use the NOAA data set after exclusion of very large values. The results (Fig. S4; Table 1) reveal that independently of using all the sites or just the main upwelling areas, the upwelling index is only significantly related to SDA in the Southern Hemispheric systems (Benguela and Humboldt - Table 1). As a whole and at the scale represented by the sediments (10 to $100 \mathrm{yr}$ ), the physics (although essential) does not appear to be the primary factor determining diatom bloom size and its sediment record.

\subsection{Primary production and SDA}

On the global scale, the restricted coastal upwelling areas are always highly associated with the spatial distribution of primary production, independently of the methodological approach (Berger, 1989; Field et al., 1998; Gregg and Conkright, 2008). There is also evidence of good agreement between NPP and sediment diatom abundance, as well as with the abundance of resting spores of Chaetoceros, the dominant genus in the sediment assemblage at the regional level (e.g., Fig. 1e and 8 in Abrantes et al., 2005, and Fig. 6 in Lopes et al., 2005). The relationship between the sediment diatom abundance data and NPP at each of these study sites is presented in Fig. 4a. Despite the generally positive relationship between SDA and NPP, a significant correlation is only observed for the Canary system region with perennial upwelling conditions (Table 1). Nonetheless, a close inspection of Fig. 4a reveals that potentially three different correlation lines can be defined through data from all different geographic locations, a result that reflects a combination of intra-regional differences and inter-regional similarities in the SDA-NPP relationship, but which hampers the possibility of defining a single equation at the global level.

\subsection{Nutrient availability and SDA}

The variables evaluated so far revealed that SDA, contrary to what has been found at the regional level, is not solely influenced by upwelling strength or ecosystem productivity. Sedimentary processes also do not appear to be a major determinant of SDA. Thus, we explored the role of nutrient availability in regulating SDA under the premise that nutrient supply ratios can select for specific phytoplankton groups (Raymont, 1980; Barber and Kogelschatz, 1990; Platt et al., 1992).

In coastal upwelling areas the type and amount of nutrients delivered to the ocean surface depend on the upwelling intensity (discussed above) since they determine the water mass source depth. Upwelled waters are, in general, central waters of sub-polar and sub-tropical origin in different mixing proportions. On a global scale, the previously mentioned interocean fractionation also causes different nutrient concentrations to exist in the Atlantic and Pacific coastal upwelling source waters. Similarly, intra-ocean circulation determines nutrient differences at the hemispheric level, in particular for silicate concentrations (Broecker and Peng, 1982; Sarmiento et al., 2003).

In coastal upwelling areas, diatoms dominate the biomass of phytoplankton communities. Their obligatory requirement for silicic acid makes it a limiting nutrient for diatom growth (Brzezinski and Nelson, 1996; Lima et al., 2014). Mesocosm experiments revealed that marine diatoms dominate phytoplankton communities when the concentration of silicic acid exceeds $2 \mu \mathrm{M}$ whenever other nutrients are in excess (Egge and Aksnes, 1992). Further analyses have shown that diatom productivity is determined by the availability of silicic acid in broad regions of the global ocean (Dugdale and Wilkerson, 1998).

Besides macronutrients, micronutrients such as iron $(\mathrm{Fe})$ are also essential for sustaining elevated rates of primary production, not only in the high-nutrient low-chlorophyll (HNLC) ocean regions (e.g., Martin et al., 1990), but also in coastal upwelling systems (Hutchins et al., 1998; Bruland et al., 2001; Hutchins et al., 2002). Despite the various potential Fe sources existing in all coastal upwelling systems, reminer- 


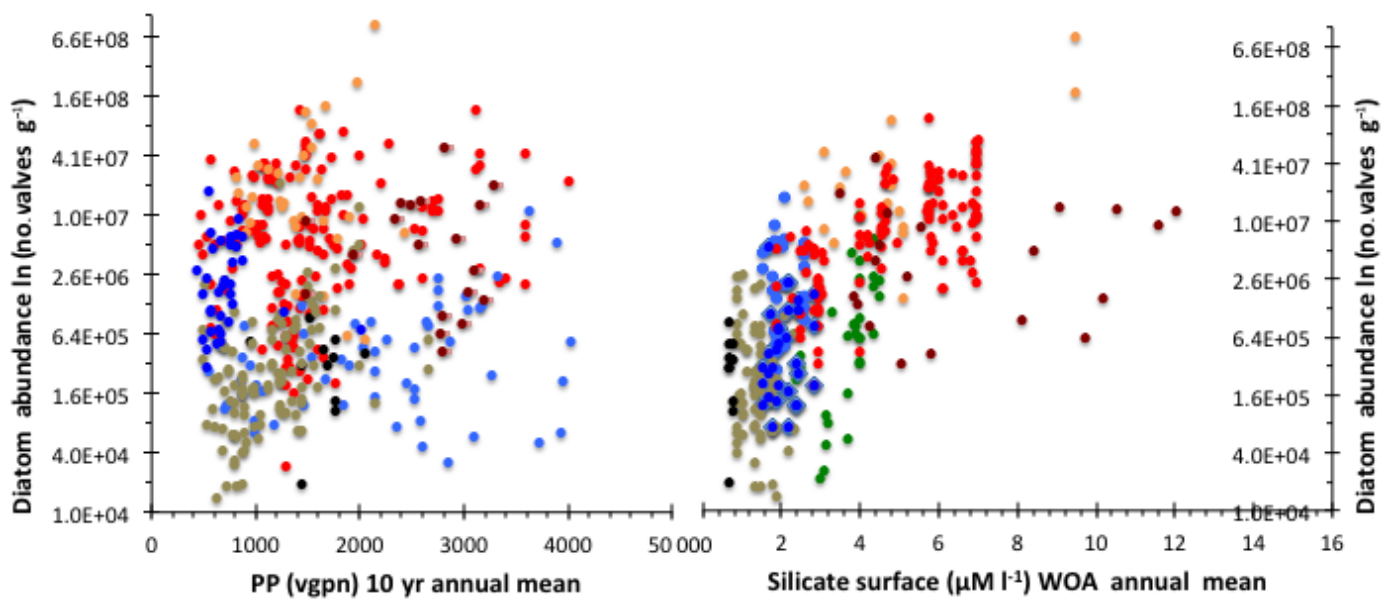

Figure 4. Relationship between total marine diatom abundance ln (no. of valves $\mathrm{g}^{-1}$ ) and (a) NPP generated from SeaWiFS chlorophyll distributions according to the Vertically Generalized Production Model (VGPM) (Behrenfeld and Falkowski, 1997), and (b) surface water $\left[\mathrm{Si}(\mathrm{OH})_{4}^{-}\right]$in $\mu \mathrm{M}$, from the WOA 2013 database. Sites located in the main upwelling areas. Color scheme as in Fig. 1.

alization within the water column, episodic inputs of Fe from continental regions (riverine or eolian input) (Boyd and Ellwood, 2010), re-suspension from the benthic boundary layer and early diagenesis remineralization of sediment $\mathrm{Fe}$, and upward diffusion of Fe-enriched pore waters (Johnson et al., 1999; Masay et al., 2014), iron limitation is currently considered an important control on phytoplankton growth in the Californian and Peruvian upwelling zones, while the Canary and Benguela systems are relatively iron-replete (Capote and Hutchins, 2013).

Fe limitation has been found to decrease diatom importance within the phytoplankton community (Hutchins, 1998); (DiTullio et al., 2005), limiting the extent of blooms to largesized $(>40 \mu \mathrm{M})$ diatoms such as Coscinodiscus (Bruland et al., 2001), and leading to thicker frustules (Pichevin et al., 2014) and higher $\mathrm{C}$ export efficiency (Brzezinski et al., 2015). However, Fe enrichment experiments in the Pacific upwelling systems produced different results for different areas. Franck et al. (2005) revealed a relative decrease in $\mathrm{Si}$ production for the Humboldt system and concluded that these regions were at first not Fe limited. DiTullio et al. (2005) consider that in upwelling systems, the luxurious Fe uptake by diatoms, near the coast, allows them to remain Fe-replete while inhabiting low-Fe waters. Conversely, Brzezinski et al. (2015) defend the finding that upwelling brings inadequate iron to the surface for phytoplankton to completely utilize macronutrients, and consider that although the $\mathrm{Fe}$ and $\mathrm{Si}$ colimitation of diatom growth observed in the HNLC equatorial Pacific system ( $\mathrm{Si}$ limits diatom $\mathrm{Si}$ uptake rates and diatom silicification, and $\mathrm{Fe}$ limits diatom growth rate) (Brzezinski et al, 2008) is lower under strong coastal upwelling, it increases along aging waters. Furthermore, in the California Current system low Fe amplifies total net opal production in different ways, depending on the $\mathrm{Si}: \mathrm{N}$ ratio of the initial up-

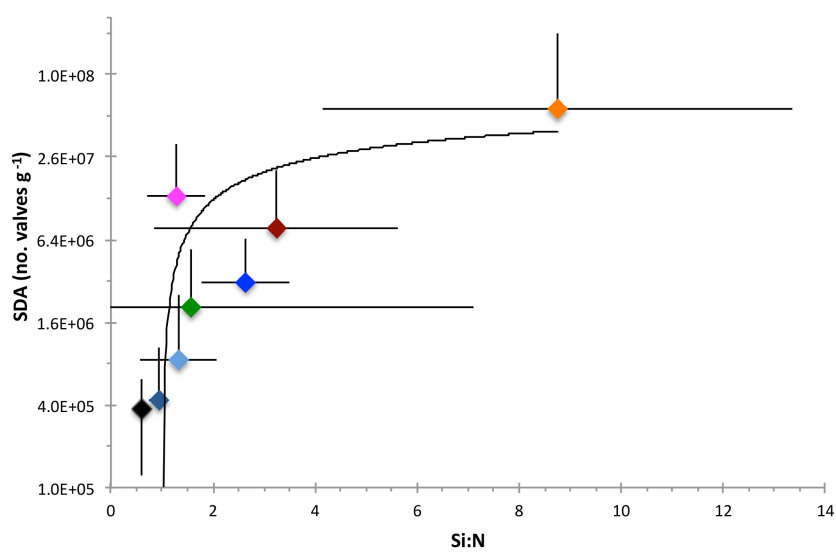

Figure 5. Relationship between average SDA $\ln \left(\right.$ no. of valves $\mathrm{g}^{-1}$ ) and average $\mathrm{Si}: \mathrm{N}$ estimated from the WOA13 database per upwelling system and considering only the true upwelling sites. Bars represent SD. Color scheme as in Fig. 1.

welled waters (Brzezinski et al., 2015). Such different results reflect the transient state of coastal upwelling systems as well as the uneven $\mathrm{Fe}$ distribution within and between regions (Hatta et al., 2014). Furthermore, the growth rate of small diatoms was not altered even in the highly Fe-limited eastern equatorial Pacific (Brzezinski et al., 2011), and coastal upwelling diatom communities are dominated by small (3$20 \mu \mathrm{M})$ Chaetoceros species known to produce heavily silicified resting spores under nutrient stress conditions.

The lack of well-distributed Fe data prevents us from assessing this micronutrient effect on SDA in the same manner as for other variables. However, spatial $\mathrm{Fe}$ variability is also accompanied by time variability (Pichevin, 2014), and as for 


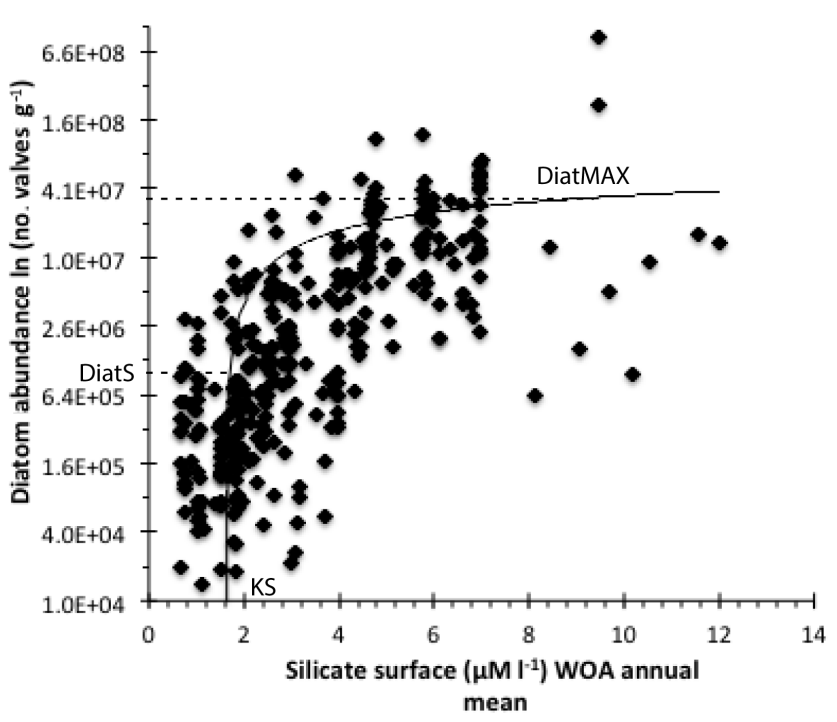

Figure 6. Translation of the Michaelis-Menten model, which defines the relationship between population abundance and [Nutrient] with the long-term SDA data set. That relationship is expressed by the mathematical equation $V=\mathrm{V}_{\max }[\mathrm{N}] /\left(K_{\mathrm{S}}+[\mathrm{N}]\right)$, where $(V)$ is the algal population growth rate, $\left(V_{\max }\right)$ is the maximum diatom abundance in the sediments (Diat ${ }_{\max }$ ) at threshold $\left[\mathrm{N}=\mathrm{Si}_{\text {surf max }}\right]$ above which population abundance remains constant, [N-Sirf $\left.\mathrm{S}_{\text {surf }}\right]$ is the silicate concentration in upwelled surface waters, and $\left(K_{\mathrm{S}}\right)$ is the silicate concentration at Diat $t_{\max } / 2$.

all other variables, the sediment record reflects the dominant state throughout the time it represents (10 to $100 \mathrm{yr}$ ).

To evaluate the large-scale spatial and temporal relation between surface water macronutrient contents and SDA, we used mean annual $\left[\mathrm{NO}_{3}^{-}\right],\left[\mathrm{PO}_{4}^{2-}\right]$, and $\left[\mathrm{Si}(\mathrm{OH})_{4}\right]$ from the WOA13 database (Table 1 and Figs. $4 \mathrm{~b}$ and S5). SDA shows a significant positive relationship with $\left[\mathrm{NO}_{3}^{-}\right]$and $\left[\mathrm{PO}_{4}^{2-}\right]$ in the Humboldt $(0.44$ and 0.52 , respectively, at $p=0.1$ and $n=162)$ and Somalia-Oman systems (0.79 and 0.67 at $p=0.1$ and $n=23$ ), but not at the global level, as is clear from Fig. S5. When the data set is restricted to the main upwelling areas, the positive relationship between SDA and nitrate becomes positive and significant $(0.39$ at $p=0.1$ and $n=400$ ), consistent with the effect of nitrate on diatom standing stocks.

Between SDA and $\left[\mathrm{Si}(\mathrm{OH})_{4}\right]$ we found a statistically significant relationship for the Canary, Humboldt, and SomaliaOman systems $(0.52,0.49$, and 0.74 , respectively - see Table 1). The relationship was also significant for the Benguela system ( 0.41 at $p=0.1$ and $n=32)$ when only the main upwelling areas are considered (Table 1; Fig. 4b).

Figures $4 \mathrm{~b}$ and S6 represent the relationship found between SDA and silicate for the main upwelling sites and the total data set, respectively, and show the same pattern but a reduction in data scattering when only the main upwelling areas are considered (Fig. 4b). In detail, it reveals a steep slope near the low silicate concentrations $(\leq 2 \mu \mathrm{M})$ defined by the northeastern Atlantic regions (Galicia to the Canary Islands region $-29^{\circ} \mathrm{N}$ ). An increase towards the asymptote is defined by the data from the Canary (Cape Blanc), Benguela, and Humboldt systems, and the sites from the Somalia-Oman and California regions, the Si-richest within the modern coastal upwelling systems, establish the maximum diatom abundances. This pattern is retained when treating the Atlantic and Pacific Ocean data sets independently (Fig. S6b, c), which confirms that the inter-hemispheric difference in preservation potential is not the main cause of the global SDA pattern.

These results led us to explore the possible link between SDA and $\left[\mathrm{Si}(\mathrm{OH})_{4}\right]$ in the surface waters using a theoretical framework focused on cell physiology. Our strategy assumes that the observed SDA reflects surface ocean diatom productivity and export fluxes (Lisitzin, 1971); Tréguer and De La Rocha, 2013). The concentration of silicic acid in upwelled waters can potentially increase SDA in two ways: (1) increasing diatom productivity (and hence diatom numerical abundance) and (2) increasing the thickness and sinking rate of diatom frustules.

According to Brzezinski et al. (2015), the ambient Si : N ratio determines the way in which $\mathrm{Fe}$ influences the total net opal production, with higher ballast (diatom species and valves more silicified and resistant to dissolution) for low $\mathrm{Si}: \mathrm{N}$ and higher $\mathrm{Si}$ production (diatom valves less silicified and resistant to dissolution) for higher $\mathrm{Si}: \mathrm{N}$ conditions. Following this logic we have investigated the influence of $\mathrm{Si}$ : N on DAR. No relationship was found, either regionally or for all the coastal upwelling systems. However, by averaging the SDA and annual $\mathrm{Si}: \mathrm{N}$ values for the main upwelling sites in each coastal upwelling system, a highly significant and positive relationship emerges $\left(R^{2}=0.64\right.$ for a $n=338$ and $p=0.1$ ). The SDA vs. $\mathrm{Si}: \mathrm{N}$ relationship throughout the five most important coastal upwelling areas (Fig. 5) follows a trend that is similar to that observed between SDA and $\left[\mathrm{Si}(\mathrm{OH})_{4}\right]$. Such results imply that in the long term (tens to hundreds of years), independently of $[\mathrm{Fe}]$ and its potential effect, it is the physiological response of marine diatoms to surface water silicic acid availability that controls coastal upwelling SDA. It has been shown that not only does diatom productivity increase with increasing silicic acid concentrations, but also that diatoms have a higher $\left[\mathrm{Si}(\mathrm{OH})_{4}\right]$ uptake rate for higher silicic acid ambient concentrations (Dugdale and Wilkerson, 1998; Goering et al., 1973; Nelson et al., 1981; Dugdale et al., 2011). Thus, we speculate that it is silicic acid concentration that sets the upper limit on diatom growth rate, which, in turn, is imposed by the physiological capacity of individual cells to take up and use silicic acid.

The dynamics of silicic acid uptake by diatoms has been a matter of continuous debate (Dugdale, 1967; Goering et al., 1973; Nelson et al., 1981; Thamatrakoln and Hildebrand, 2008), but it is traditionally parameterized by a MichaelisMenten model, defined by two parameters, the maximum 
uptake rate and the half-saturation constant (i.e., the concentration of a nutrient at which the population reaches half of the maximum uptake rate; Del Amo and Brzezinski, 1999). We applied the mathematical expression used to model nutrient uptake kinetics to our SDA data on the regional, oceanic, hemispheric, and global scales:

$$
V=V_{\max }\left(\left[\mathrm{Si}(\mathrm{OH})_{4 \max }\right] / K_{\mathrm{s}}+\left[\mathrm{Si}(\mathrm{OH})_{4 \max }\right]\right),
$$

where $V_{\max }$ is considered to be the maximum diatom abundance value (Diat $\left.{ }_{\max }\right)$ defined by the best line fit $(\log )$ to the data, $[\mathrm{S}]$ the concentration of silicic acid $\left(\mathrm{Si}_{\text {surf max }}\right)$, and $K_{\mathrm{S}}$ the half-saturation constant defined as $\left(\right.$ Diat $\left._{\mathrm{s}}\right)=\left(\right.$ Diat $\left._{\max } / 2\right)$ (e.g., Fig. 6).

The results obtained are presented in Table S1, where the parameter $V$ represents the expected sediment diatom abundance at a given silicic acid concentration in the surface ocean waters. $V$ values are on the order of $10^{8}$ for a silicic acid concentration $\pm 7 \mu \mathrm{ML}^{-1}$ in the Pacific and Indian upwelling areas, as well as for all five areas together. For the Southern Hemisphere coastal upwelling systems, the values were on the order of $10^{7}$ for the same $\left[\mathrm{Si}(\mathrm{OH})_{4}\right], \pm 7 \mu \mathrm{MzL}^{-1}$. The parameter $V$ in the Atlantic Ocean is 1 order of magnitude lower than in the Southern Hemisphere systems and 2 orders of magnitude lower than in the Pacific Ocean or all five areas together. Similarly, a $\left[\mathrm{Si}(\mathrm{OH})_{4}\right]$ yield dose of $1 \mu \mathrm{Mz} \mathrm{L}^{-1}$ in the Atlantic and the Northern Hemisphere (excluding the Somalia-Oman system) suggests that in these oceanic regions marine diatoms are out-competed by non-siliceous phytoplankton, in agreement with observations in mesocosm experiments (Egge and Aksnes, 1992).

\section{Conclusions}

In summary, our results indicate that SDA is not dependent on sedimentation rate nor is it solely a function of the bottom-water silicate concentration. On decadal to centennial timescales, nitrate and silicic acid concentrations in surface waters contribute to defining the global SDA pattern. However, the ability of marine diatoms to take up silicic acid sets an upper limit to SDA that strongly influences the potential of coastal upwelling areas for $\mathrm{C}$ sequestration.

\section{Data availability}

The entire datasets are available at doi:10.1594/PANGAEA.859881.

The Supplement related to this article is available online at doi:10.5194/bg-13-4099-2016-supplement.
Acknowledgements. This study was supported by the following projects: CUPEX (PDCT/MAR/56963/2004) and Diatbio (PTDC/AAG-GLO/3737/2012). The authors thank Cremilde Monteiro and Apolónia Inês for their laboratory support and L. Dewitt for her help with the upwelling index calculation

Edited by: Fei Chai

Reviewed by: two anonymous referees

\section{References}

Abrantes, F.: Diatom assemblages as upwelling indicators in surface sediments in Portugal, Mar. Geol., 85, 15-39, 1988.

Abrantes, F.: 200 ka Diatom Records from Atlantic Upwelling sites Reveal Maximum Productivity during LGM and a Shift in Phytoplankton Community Structure at $185 \mathrm{ka}$, Earth Planet. Sci. Lett., 176, 7-16, 2000.

Abrantes, F. and Moita, T.: Water Column and Recent Sediment Data on Diatoms and Coccolithophorids, off Portugal, Confirm Sediment Record as a Memory of Upwelling Events, Oceanol. Acta, 22, 319-336, 1999.

Abrantes, F., Meggers, H., Nave, S., Bollman, J., Palma, S., Sprengel, C., Hendericks, J., Spies, A., Salgueiro, E., Moita, T., and Neuer, S.: Fluxes of micro-organisms along a productivity gradient in the Canary Islands region $\left(29^{\circ} \mathrm{N}\right)$ : implications for paleoreconstructions, Deep-Sea Res. Pt. II, 49, 3599-3629, 2002.

Abrantes, F. I. G., Lopes, C., and Castro, M.: Quantitative diatom analyses - a faster cleaning procedure, Deep-Sea Res. Pt. I, 52, 189-198, 2005.

Abrantes, F., Lopes, C., Mix, A., and Pisias, N.: Diatoms in Southeast Pacific surface sediments reflect environmental properties, Quaternary Sci. Rev., 26, 155-169, 2004.

Bakun, A.: Coastal upwelling indices, west coast of North America, 1946-1971, 403 NOAA Technical Report NMFS SSRF-671, 103 pp., 1973.

Barber, R. and Kogelschatz, J.: Nutrients and Productivity during the 1982/83 El Niño, in: Global Ecological Consequences of the 1982-1983 El Nino-Southern Oscillation, edited by: Glyn, P., Elsevier, New York, 1990.

Barber, R. and Smith, R.: Coastal Upwelling Ecosystems, in: Analysis of Marine Ecosystems, edited by: Longhurst, A. R., Academic Press, New York, 31-68, 1981.

Barber, R. T. and Smith, R. L.: Coastal Upwelling Ecosystems, in: Analysis of Marine Ecosystems, edited by: Longhurst, A. R., Academic Press, New York, 31-68, 1984.

Behrenfeld, M. and Falkowski, P.: Photosynthetic rates derived from satellite-based chlorophyll concentration, Limnol. Oceanogr., 42, 1-20, 1997.

Berger, W. H.: Global Maps of Ocean Productivity, in: Productivity of the Ocean: Present and Past, edited by: Berger, W. H., Smetacek, V. S., and Wefer, G., Life Sciences Research Reports, John Wiley \& Sons, New York, 1989.

Boyd, P. W. and Ellwood, M. J.: The biogeochemical cycle of iron in the ocean, Nat. Geosci., 3, 675-682, 2010.

Broecker, W. S. and Peng, T. H.: Tracers in the sea, in: Tracers in the sea, edited by: Broecker, W. S., Eldigio Press, New York, 702 pp., 1982. 
Bruland, K. W., Rue, E. L., and Smith, G. J.: Iron and macronutrients in California coastal upwelling regimes: Implications for diatom blooms, Limnol. Oceanogr., 46, 1661-1674, 2001.

Brzezinski, M. and Nelson, D.: Chronic substrate limitation of silicic acid uptake rates in the western Sargasso Sea, Deep-Sea Res. Pt. II, 43, 437-453, 1996.

Brzezinski, M., Baines, S. B., Balch, W. M., Beucher, C. P., Chai, F., Dugdale, R., Krause, J. W., Landry, M. R., Marchi, A., Measures, C., Nelson, D., Parker, A. E., Poultron, A. J., Selph, K. E., Strutton, P. G., Taylor, A. G., and Twining, B. S.: Co-limitation of diatoms by iron and silicic acid in the equatorial Pacific, DeepSea Res. Pt. II, 58, 493-511, 2011.

Brzezinski, M., Krause, J. W., Bundy, R. M., Barbeau, K. A., Franks, P., Goericke, R., Landry, M. R., and Stuke, M. R.: Enhanced silica ballasting from iron stress sustains carbon export in a frontal zone within the California Current, J. Geophys. Res.Ocean., 120, 4654-4669, 2015.

Canfield, D. E.: Factors influencing organic carbon preservation in marine sediments, Chem. Geol., 114, 315-329, 1994.

Capote, D. G. and Hutchings, D. A.: Microbial biogeochemistry of coastal upwelling regimes in a changing ocean, Nature Geosci, 6, 711-717, 2013.

Caulet, J.-P., Vénec-Peyré, M.-T., Vergnaud-Grazzini, C., and Nigrini, C.: Variations of South Somalian upwelling during the last $160 \mathrm{ka}$ : radiolarian and foraminifera records in core MD 85674 , in: Upwelling Systems: Evolution Since the Early Miocene, edited by: Summerhayes, C., Prell, W., and Emeis, K., The Geological Society, London, 1992.

Del Amo, Y. and Brzezinski, M. A.: The chemical form of dissolved Si taken up by marine diatoms, J. Phycol., 35, 1162-1170, 1999.

DiTullio, G. R., Geesey, M. E., Maucher, J. M., Alm, M. B., Riseman, S. F., and Bruland, K. W.: Influence of iron on algal community composition and physiological status in the Peru upwelling system, Limnol. Oceanogr., 50, 1887-1907, 2005.

Dugdale, R. and Wilkerson, F. P.: Silicate regulation of new production in the equatorial Pacific upwelling, Nature, 391, 270-273, 1998.

Dugdale, R., Chai, F., Feely, R., Measures, C., Parker, A., and Wilkerson, F. P.: The regulation of equatorial Pacific new production and $p \mathrm{CO}_{2}$ by silicate-limited diatoms, Deep-Sea Res. Pt. II, 58, 477-492, 2011

Dugdale, R. C.: Nutrient limitation in the sea: dynamics, identification, and significance, Limnol. Oceanogr., 12, 685-695, 1967.

Egge, J. K. and Aksnes, D.: Silicate as regulating nutrient in phytoplankton competition, Mar. Ecol.. Prog. Ser., 83, 281-289, 1992.

Emerson, S.: Organic Carbon Preservation in Marine Sediments, in: The Carbon Cycle and Atmospheric CO: Natural Variations Archean to Present, edited by: Sundquist, E. T. and Broecker, W. S., American Geophysical Union, Washington, DC, 1985.

Estrada, M. and Blasco, D.: Phytoplankton assemblages in coastal upwelling areas, in: Simposio Internacional sobre las areas de afloramiento mas importantes del oeste Africano, (Cabo Blanco y Benguela), edited by: Bas, C., Margalef, R., and Rubies, P., Instituto de Investigaciones Pesqueras, Barcelona, 1985.

Field, C., Behrenfeld, M., Randerson, J. T., and Falkowski, P.: Primary Production of the Biosphere: Integrating Terrestrial and Oceanic Components, Science, 281, 237-240, 1998.

Garcia, H. E., Locarnini, R. A., Boyer, T. P., Antonov, J. I., Baranova, O. K., Zweng, M. M., Reagan, J. R., and Johnson, D. R.:
World Ocean Atlas 2013, Volume 4: Dissolved Inorganic Nutrients (phosphate, nitrate, silicate), edited by: Levitus, S., in: NOAA Atlas NESDIS 76, A. Mishonov Technical Ed., NODC, 2014.

Franck, V. M., Smith, G. J., Bruland, K. W., and Brzezinski, M.: Comparison of size-dependent carbon, nitrate, and silicic acid uptake rates in high- and low-iron waters, Limnol. Oceanogr., 50, 825-838, 2005.

Goering, J. J., Nelson, D. M., and Carter, J. R.: Silicic acid uptake by natural populations of marine phytoplankton, Deep-Sea Res. Pt. I, 20, 777-789, 1973.

Gregg, W. and Conkright, M.: Global Seasonal Climatologies of Ocean Chlorophyll: Blending In situ and Satellite Data for the CZCS Era NOAA, National Oceanographic Data Center (NODC), 2008.

Hatta, M., Measures, C., Wu, J., Roshan, S., Fitzsimmons, N., and Sedwick, P. N.: An overview of dissolved Fe and $\mathrm{Mn}$ Distributions during the 2010-2011 U.S. GEOTRACES north Atlantic Cruises: GEOTRACES GA03, Deep-Sea Res. Pt. II, doi:10.1016/j.dsr2.2014.07.005, 2014.

Heinze, P. and Wefer, G.: The history of coastal upwelling off Peru $\left(11^{\circ} \mathrm{S}\right.$, ODP Leg 112 , Site $\left.680 \mathrm{~B}\right)$ over the past 650000 years, in: Upwelling Systems: Evolution Since the Early Miocene, edited by: Summerhayes, C., Prell, W., and Emeis, K., The Geological Society, London, 1992.

Hill, E. A., Hickey, B. M., Shillington, F. A., Strub, P. T., Brink, K. H., Barton, E. D., and Thomas, A. C.: Eastern Ocean Boundaries Coastal Segment (E), in: The Sea, edited by: Robinson, A. R. and Brink, K. H., John Wiley \& Sons, Inc., New York, 1998.

Hurd, D. C. and Takahashi, K.: On the Estimation of Minimum Mechanical Loss During an in situ Biogenic Silica Dissolution Experiment, Elsevier Scientific Publishing Company, Amsterdam, 1982.

Hutchins, D., DiTullio, G. R., Zhang, Y., and Bruland, K. W.: An iron limitation mosaic in the California upwelling regime, Limnol. Oceanogr., 43, 1037-1054, 1998.

Hutchins, D. A., Hare, C. E., Weaver, R. S., Zhang, Y., Firme, G. F., DiTullio, G. R., Alm, M. B., Riseman, S. F., Maucher, J. M., Geesey, M. E., Trick, C. G., Smith, G. J., Rue, E. L., Conn, J., and Bruland, K. W.: Phytoplankton iron limitation in the Humboldt Current and Peru Upwelling, Limnol. Oceanogr., 47, 997-1011, 2002.

Johnson, K. S., Chavez, F. P., and Friederich, G. E.: Continentalshelf sediment as a primary source of iron for coastal phytoplankton, Nature, 398, 697-700, 1999.

Koning, E., van Iperen, J. M., van Raaphorst, W., Helder, W., Brummer, G.-J. A., and van Weering, T. C. E.: Selective preservation of upwelling-indicating diatoms in sediments off Somalia, NW Indian Ocean, Deep-Sea Res. Pt. I, 48, 2473-2495, 2001.

Lange, C. B., Treppke, U. F., and Fischer, G.: Seasonal diatom fluxes in the Guinea Basin and their relationships to trade winds, hydrography and upwelling events, Deep-Sea Res. Pt. I, 41, 859878, 1994.

Lewin, J. and Guillard, R. R. L.: DIATOMS, Annu. Rev. Microbiol., 17, 373-414, 1963.

Lima, I. D., Lam, P. J., and Doney, S. C.: Dynamics of particulate organic carbon flux in a global ocean model, Biogeosciences, 11, 1177-1198, doi:10.5194/bg-11-1177-2014, 2014. 
Lisitzin, A. P.: Distribution of Siliceous Microfossils in Suspension and in Bottom Sediments, in: The micropaleontology of the Oceans, Cambridge University Press, London, 1971.

Lopes, C., Mix, A., and Abrantes, F.: Diatom Transfer Functions for Sea Surface Temperature and Productivity in Upwelling Regimes: A Canonical Correspondence Analysis Approach, Viena, 24-29 April 2005, EUG05-A-01079, 2005.

Lopes, C., Mix, A. C., and Abrantes, F.: Diatoms in northeast Pacific surface sediments as paleoceanographic proxies, Mar. Micropaleontol., 60, 45-65, 2006.

Lopes, C., Kucera, M., and Mix, A.: Climate change decouples oceanic primary and export productivity and organic carbon burial, PNAS, 112, 2, doi:10.1073/pnas.1410480111, 2014.

Lyle, M., Marcantonio, F., W. S. Moore, Murray, R. W., Huh, C.-A., Finney, B. P., Murray, D. W., and Mix, A. C.: Sediment size fractionation and focusing in the equatorial Pacific: Effect on ${ }^{230} \mathrm{Th}$ normalization and paleoflux measurements, Paleoceanography, 29, 747-763, 2014.

Martin, J. H., Fitzwater, S. E., and Gordon, M.: Iron Deficiency limits Phytoplankton Growth in Antarctic Waters, Global Biogeochem. Cy., 4, 5-12, 1990.

Martinez, P., Bertrand, P., Shimmield, G. B., Cochrane, K., Jorissen, F. J., Foster, J., and Dignan, M.: Upwelling intensity and ocean productivity changes off Cape Blanc (northwest Africa) during the last 70,000 years: geochemical and micropalaeontological, Mar. Geol., 158, 57-74, 1999.

Masay, C. M., Sedwick, P. N., Dinniman, M. S., Barrett, P. M., Mack, S. L., and McGillicuddy Jr., D. J.: Estimating the benthic efflux of dissolved iron on the Ross Sea continental shelf, Geophys. Res. Lett., 41, 7576-7583, 2014.

Muller, P. J. and Suess, E.: Productivity, sedimentation rate, and sedimentary organic matter in the oceans - I. Organic carbon preservation, Deep-Sea Res. A, 26, 1347 pp., 1979.

Nair, R. R., Ittekkot, V., Manganini, S. J., Ramaswamy, V., Haake, B., Degens, E. T., Desai, B. N., and Honjo, S.: Increased particle flux to the deep ocean related to monsoons, Nature, 338, 749$751,1989$.

Nave, S., Freitas, P., and Abrantes, F.: Coastal upwelling in the Canary Island region: spatial variability reflected by the surface sediment diatom record, Mar. Micropaleontol., 42, 1-23, 2001.

Nelson, D., Tréguer, P., Brzezinski, M., Leynaert, A., and Quéguiner, B.: Production and dissolution of biogenic silica in the ocean: Revised global estimates, comparison with regional data and relationship to biogenic sedimentation, Global Biogeochem. Cy., 9, 359-372, 1995.

Nelson, D. M., Goering, J. J., and Boisseau, D. W.: Consumption and Regeneration of Silicic Acid in three Coastal Upwelling Systems, in: Coastal Upwelling, edited by: Richard, F. A., AGU, Washington, 1981.

Philander, S. G. H.: El Niño, La Niña, and the Southern Oscillation, Academic Press, San Diego, 289 pp., 1990.

Pichevin, L. E., Ganeshram, R. S., Geibert, W., Thunell, R., and Hinton, R.: Silica burial enhanced by iron limitation in oceanic upwelling margins, Nat. Geosci., 7, 541-546, doi:10.1038/NGEO2181, 2014.

Platt, T., Sathyendranath, S., Ulloa, O., Harrison, W. G., Hoepffner, N., and Goes, J.: Nutrient control of phytoplankton photosynthesis in the Western North Atlantic, Nature, 356, 229-231, 1992.
Rageneau, O., Tréguer, P., Anderson, R., Brzezinski, M., and DeMaster, D. J.: A review of the Si cycle in the modern ocean recent progress and missing gaps in the application of biogenic opal pump, Global Biogeochem. Cy., 20, 317-365, 2000.

Raymont, J.: Plankton and Productivity in the Oceans, Pergamon Press, Oxford, 489 pp., 1980.

Reimers, C. and Suess, E.: Late Quaternary fluctuations in the cycling of organic matter off central Peru: A proto-kerogen record, in: Coastal Upwelling Its Sediment Record, edited by: Suess, J. T. a. E., Plenum-Press, 1983.

Romero, O., Hebbeln, D., and Wefer, G.: Temporal and spatial variability in export production in the SE Pacific Ocean, evidence from siliceous plankton fluxes and surface sediment assemblages, Deep-Sea Res., 48, 2673-2697, 2001.

Romero, O., Boeckel, B., Donner, B., Lavik, G., Fischer, G., and Wefer, G.: Seasonal productivity dynamics in the pelagic central Benguela System inferred from the flux of carbonate and silicate organisms, J. Mar. Syst., 37, 259-278, 2002.

Rykaczewski, R., Dunne, J. P., Sydeman, W., García-Reyes, M., Black, B., and Bograd, S.: Poleward displacement of coastal upwelling favorable winds in the ocean's eastern boundary currents through the 21st century, Geophys. Res. Lett., 42, 6424-6431, doi:10.1002/2015GL064694, 2015.

Sancetta, C.: Comparison of phytoplankton in sediment trap series and surface sediments along productivity gradient, Paleoceanography, 7, 183-194, 1992.

Sancetta, C.: Diatoms in the Gulf of California: Seasonal flux patterns and the sediment record for the last 15,000 years, Paleoceanography, 10, 67-84, 1995.

Sarmiento, J. L., Gruber, N., Brzezinski, M., and Dunne, J. P.: Highlatitude controls of thermocline nutrients and low latitude biological productivity, Nature, 427, 56-60, 2003.

Schrader, H. and Gersonde, R.: Diatoms and Silicoflagellates, Utrecht Micropaleontological Bulletins, 17, 129-176, 1978.

Schuette, G. and Schrader, H.: Diatom Taphocoenoses in the Coastal Upwelling Area off South West Africa, Elsevier Scientific Publishing Company, Amsterdam, 1981.

Takahashi, K., Honjo, S., and Tabata, S.: Siliceous phytoplankton flux: interannual variability and response to hydrographic changes in the northeastern Pacific, in: Aspects of Climate Variability in the Pacific and Western Americas, edited by: Peterson, D., American Geophysical Union, 1989.

Thamatrakoln, K. and Hildebrand, M.: Silicon Uptake in Diatoms Revisited: A Model for Saturable and Nonsaturable Uptake Kinetics and the Role of Silicon Transporters, Plant Physiol., 146, 1397-1407, 2008.

Tréguer, P. J. and De La Rocha, C. L.: The World Ocean Silica Cycle, Annu. Rev. Mar. Sci., 5, 5.1-5.25, 2013.

Treppke, U., Lange, C., Dormer, B., Fischer, G., Ruhlandl, G., and Wefer, G.: Diatom and silicoflagellate fluxes at the Walvis Ridge: An environment influenced by coastal upwelling in the Benguela system, J. Mar. Res., 54, 991-1016, 1996a.

Treppke, U., Lange, C., and Wefer, G.: Vertical fluxes of diatoms and silicoflagellates in the eastern equatorial Atlantic, and their contribution to the sedimentary record, Mar. Micropaleontol., 28, 73-96, 1996b.

Van Bennekom, A. J. and Berger, G. W.: Hydrography and silica budget of the Angola Basin, Neth. J. Sea Res., 17, 149-200, 1984. 
Van Cappellen, P., Dixit, S., and van Beusekom, J.: Biogenic silica dissolution in the oceans: Reconciling experimental and fieldbased dissolution rates, Global Geochem. Cy., 16, 23-1-23-10, 2002.

Wefer, G. and Fisher, G.: Seasonal Patterns of Vertical Flux in Equatorial and Coastal Upwelling Areas of the Eastern Atlantic, Deep-Sea Res. Pt. I, 40, 1613-1645, 1993.
Zonneveld, K. A. F., Versteegh, G. J. M., Kasten, S., Eglinton, T. I., Emeis, K.-C., Huguet, C., Koch, B. P., de Lange, G. J., de Leeuw, J. W., Middelburg, J. J., Mollenhauer, G., Prahl, F. G., Rethemeyer, J., and Wakeham, S. G.: Selective preservation of organic matter in marine environments; processes and impact on the sedimentary record, Biogeosciences, 7, 483-511, doi:10.5194/bg-7483-2010, 2010. 